\title{
Potassium nutrition in sugar cane ratoons cultured in red latosol with a conservationist system
}

\author{
V. S. Cavalcante, R. M. Prado, H. J. Almeida, T. M. R. Silva, R. A. Flores \& M. A. \\ Pancelli
}

To cite this article: V. S. Cavalcante, R. M. Prado, H. J. Almeida, T. M. R. Silva, R. A. Flores \& M. A. Pancelli (2016) Potassium nutrition in sugar cane ratoons cultured in red latosol with a conservationist system, Journal of Plant Nutrition, 39:3, 315-322, DOI: 10.1080/01904167.2015.1009111

To link to this article: https://doi.org/10.1080/01904167.2015.1009111

Accepted author version posted online: 05

Feb 2015.

Published online: 05 Feb 2015.

Submit your article to this journal ¿

Џ Article views: 86

View Crossmark data ¿

Citing articles: 1 View citing articles 


\title{
Potassium nutrition in sugar cane ratoons cultured in red latosol with a conservationist system
}

\author{
V. S. Cavalcante, R. M. Prado, H. J. Almeida, T. M. R. Silva, R. A. Flores, and M. A. Pancelli \\ Department of Soils and Fertilizers, State University of Sao Paulo (UNESP), Jaboticabal, Brazil
}

\begin{abstract}
The aim of this study was to evaluate the effect of potassium addition to the soil in first and second ratoon sugarcane cultures in a conservationist system. The experiment was conducted at the State of Sao Paulo, Brazil, in an Acriferric Red Latosol cultured with a IAC SP 93-3046 cane sugar variety after plant-cane cutting. The experiment involved five potassium treatments and four repetitions in randomized block design. The potassium (K) dosages were $27,54,108$, and $162 \mathrm{~kg} \mathrm{~K} \mathrm{ha}^{-1}$, and a treatment without potassium. Six months after the start of the experiment, soil samples collected at 0-20 and 20-40 cm in depth were analyzed for K content. Four months after sprouting, plants were evaluated, by tiller numbers, height, diameter, technological analysis of stalks, and nutritional status. In the first ratoon, potassium fertilization increased stalk diameters, increased potassium accumulation in the aerial parts, and increased stalk production. In the second ratoon, there was a water deficiency, and soil application of potassium did not influence plant growth, nutritional status, or production parameters. Application of potassium in cane sugar ratoons did not contribute to stalk technological quality.
\end{abstract}

\section{ARTICLE HISTORY}

Received 21 April 2013

Accepted 6 February 2014

\section{KEYWORDS}

Plant nutrition; soil fertility; sugarcane; quality; straw covering; stalk production

\section{Introduction}

One of the main cultures in Brazil, sugar cane harvested in the 2012/2013 season covered 8527.8 million hectares with a productivity of $70 \mathrm{tha}^{-1}$ (Conab, 2012). Straw removal by fire as in the traditional harvest system produced many environmental problems that led to changes imposed by new legislation (Ageitec, 2013).

The changed harvest system, without fire, leaves a straw covering in the cultured area, quantified as something between 10-30 $\mathrm{t} \mathrm{ha}^{-1}$ annum ${ }^{-1}$ as dry matter (Cantarella, 1998), an action which increases organic matter levels and improves soil fertility (Mendonza et al., 2000). Decomposed straw liberates nutrients into the soil, mainly potassium in a yield of $85 \%$ of the quantity initially held by the residue (56 $\mathrm{kg} \mathrm{ha}^{-1}$ ) (Oliveira et al., 1999).

The changes in the agricultural ecosystem introduced by fireless harvest means that fertilization management should be reformulated in ratoon cane sugar cultures, a condition that requires potassium as a main ingredient, in a dosage of $1.5 \mathrm{~kg}$ of potassium oxide $\left(\mathrm{K}_{2} \mathrm{O}\right)$ for each ton ha ${ }^{-1}$ of cane produced (Oliveira, 2008). In tropical soils with generally poor availability of potassium, fertilization with this nutrient is expected to induce positive responses in sugar cane cultures. For soils showing low levels of potassium (K), it is suggested the application of $108 \mathrm{~kg} \mathrm{~K} \mathrm{ha}^{-1}$ for a harvest of 80 to $100 \mathrm{t} \mathrm{ha}^{-1}$ by the system of straw burning (Spironello et al., 1997; Reis Junior, 2001; Benedini and Penatti, 2008).

CONTACT V.S.Cavalcante valeriasantos_88@hotmail.com Department of Soils and Fertilizers, Faculty of Agrarian and Veterinarian Sciences, State University of Sao Paulo (UNESP), Jaboticabal SP 14884-900, Brazil.

๑ 2016 Taylor and Francis Group, LLC 
Low $\mathrm{K}$ levels in soil contribute to reduce the longevity of sugar cane fields (Schultz et al., 2010) and $\mathrm{K}$ is considered an essential element in the productivity recovery of sugar cane ratoons (Weber et al., 2002).

Notwithstanding the importance of $\mathrm{K}$ for sugar cane ratoons, studies on fertilization with this nutrient are restricted to plant-cane or to ratoons of harvest systems that remove straw field by fire. Therefore, information on conservationist systems that do not use elimination of straw by fire is scarce.

The aim of this study was to evaluate the effects of potassium applied to soil in first and second cane sugar ratoon cultures conducted in a Red Latosol by a conservationist system.

\section{Materials and methods}

The experiment was conducted in a cane sugar ratoon, cultured in an acriferric Red Latosoil, with clay texture (Embrapa, 2006), located at the Chapadao Farm, city of Jardinopolis, Sao Paulo, at $20^{\circ} \mathrm{S}$, $57^{\prime} 748^{\prime \prime}$ latitude and WO $47^{\circ}, 43^{\prime} 991^{\prime \prime}$ longitude, and $704 \mathrm{~m}$ above sea level. The region climate is classified by Koppen as Aw, a humid tropical climate with rain in the summer and dry in the winter. Data (hydric balance) was from the nearest meteorological station to the experimental field (Table 1).

The variety of sugar cane used in the experimental ratoons was IAC SP 93-3046 after plant-cane cutting. Before assay implantation, 20 plain soil samples were collected in the area, from depths $0-20$ and $20-40 \mathrm{~cm}$ to form a composed sample. Chemical analysis of the soil samples (Table 2) was made according to the methods described by van Raij et al. (2001).

Straw covering the culture soil in both the first and second ratoon was collected from three $1 \mathrm{~m}^{2}$ random locations each, corresponding to dry matter of $9 \mathrm{t} \mathrm{ha}^{-1}$ and $20.5 \mathrm{t} \mathrm{ha}^{-1}$, respectively. The nutrient levels in straw from both ratoons were determined by chemical analysis according to the method described by Bataglia et al. (1983) with the following results: nitrogen $(\mathrm{N})=8.6$; phosphorus $(\mathrm{P})=0.5$; potassium $(\mathrm{k})=5.3$; calcium $(\mathrm{Ca})=3.5$; magnesium $(\mathrm{Mg})=0.9$; sulfur $(\mathrm{S})=4.4 \mathrm{~g} \mathrm{~kg}^{-1}$ in the first ratoon and $\mathrm{N}=5.0 ; \mathrm{P}=0.3 ; \mathrm{K}=3.2 ; \mathrm{Ca}=2.8 ; \mathrm{Mg}=1.0 ; \mathrm{S}=1.4 \mathrm{~g} \mathrm{~kg}^{-1}$ in the second ratoon.

The experiment was designed in randomized complete blocks with five treatments and four repetitions. The experimental units were composed by parcels containing four lines each $15 \mathrm{~m}$ long (line spacing of $1.4 \mathrm{~m}$ ), and evaluations were made in the two central lines of each parcel.

Treatments consisted of $\mathrm{K}$ dosages applied to the soil, and taken in reference to the one recommended for the State of Sao Paulo, $108 \mathrm{~kg} \mathrm{~K} \mathrm{ha}^{-1}$ (Spironello et al., 1997) and one control without addition of the nutrient. Therefore, the $\mathrm{K}$ dosages were 27; 54; 108 and $162 \mathrm{~kg} \mathrm{~K} \mathrm{ha}^{-1}$, corresponding to $25,50,100$, and $150 \%$ of the reference dosage, dispensed as potassium chloride $\left(60 \% \mathrm{~K}_{2} \mathrm{O}\right)$. The fertilizer was applied alongside the ratoon lines without incorporation as preconized by Spironello et al.

Table 1. Hydric balance in the 2009-2010 and 2010-2011 periods in the city of Ribeirão Preto, Sp.

\begin{tabular}{|c|c|c|c|c|}
\hline \multirow[b]{2}{*}{ Months } & \multicolumn{2}{|c|}{ 2009-2010 (First ratoon) } & \multicolumn{2}{|c|}{ 2010-2011 (Second ratoon) } \\
\hline & Deficiency & Surplus & Deficiency & Surplus \\
\hline June & 0.00 & 0.00 & -28.57 & 0.00 \\
\hline July & -13.68 & 0.00 & -40.58 & 0.00 \\
\hline Aug. & 0.00 & 0.00 & -64.84 & 0.00 \\
\hline Sept. & 0.00 & 69.51 & -8.06 & 0.00 \\
\hline Oct. & 0.00 & 11.03 & -27.51 & 0.00 \\
\hline Nov. & 0.00 & 77.49 & 0.00 & 0.00 \\
\hline Dec. & 0.00 & 184.26 & 0.00 & 0.00 \\
\hline Jan. & 0.00 & 130.60 & 0.00 & 63.99 \\
\hline Feb. & 0.00 & 26.49 & 0.00 & 59.05 \\
\hline Mar. & 0.00 & 31.21 & 0.00 & 374.26 \\
\hline Apr. & -6.76 & 0.00 & -0.50 & 0.00 \\
\hline May & -21.81 & 0.00 & -18.12 & 0.00 \\
\hline
\end{tabular}

Source: CIIAGRO, 2003. 
Table 2. Soil chemical characteristics of the sugar cane experimental area before initiation of the experiment.

\begin{tabular}{|c|c|c|c|c|c|c|c|c|c|c|}
\hline \multirow[b]{2}{*}{ Layer } & \multirow[b]{2}{*}{$\mathrm{pH}\left(\mathrm{CaCl}_{2}\right)$} & \multirow{2}{*}{$\begin{array}{c}\mathrm{mg} \mathrm{dm}^{-3} \\
\mathrm{P}\end{array}$} & \multirow{2}{*}{$\begin{array}{l}\mathrm{g} \mathrm{dm}^{-3} \\
\text { M.O. }^{*}\end{array}$} & \multicolumn{6}{|c|}{$\mathrm{mmol}_{\mathrm{c}} \mathrm{dm}^{-3}$} & \multirow{2}{*}{$\begin{array}{l}\mathrm{V}^{*} \\
\%\end{array}$} \\
\hline & & & & $\mathrm{K}$ & $\mathrm{Ca}$ & $\mathrm{Mg}$ & $\mathrm{H}+\mathrm{Al}^{*}$ & $T^{*}$ & $\mathrm{SB}^{*}$ & \\
\hline $0-20$ & 5.3 & 18 & 28 & 0.8 & 38 & 8 & 28 & 74.8 & 46.8 & 63 \\
\hline $20-40$ & 5.4 & 15 & 32 & 0.9 & 42 & 10 & 31 & 83.9 & 52.9 & 63 \\
\hline
\end{tabular}

*M.O- organic matter; H+AL- potential acidity; T- potential capacity for cation exchange; SB- base sum; V- base saturation.

(1997). Additional $\mathrm{N}$ and $\mathrm{P}$ fertilization according to the same author, consisted of $13.10 \mathrm{~kg} \mathrm{P} \mathrm{ha}^{-1}$ as diammonium phosphate (DAP) and $100 \mathrm{~kg} \mathrm{ha}^{-1} \mathrm{~N}$ as ammonium sulfate and was applied in an uniform way to all portions. Fertilization was applied 30 days after plant-cane cutting (full plant sprouting) and repeated in the same period after the first ratoon cutting.

Thirty days after sugar cane sprouting, a post-emergent herbicide was applied (Advance ${ }^{\circledR}$, Griffin Brazil Ltd., Rio de Janeiro, Brazil) in the dosage of $3 \mathrm{~kg} \mathrm{ha}^{-1}$ for weed control.

Six months after sugar cane sprouting, soil samples were collected close to the culture line (fertilization strip), at depths of $0-20$ and $20-40 \mathrm{~cm}$ in 10 random points in the parcels. The soil samples were analyzed chemically for K levels by the method described by van Raij et al. (2001).

Plant growth evaluation in the first and second ratoons was conducted 4 months after sprouting by determining the number of tillers in plants growing in $1.5 \mathrm{~m}$ of each experimental unit. Plant height was considered from soil surface to leaf sheath +1 , and stalk joint was diameter determined by a digital pachymeter halfway the first stalk joint in 10 plants experimental unit ${ }^{-1}$.

Plant nutritional estate was determined 8 months after ratoon sprouting by collecting 10 leaves experimental unit ${ }^{-1}$. The leaves considered +1 were the highest ones with a visible sheath (Top Visible Dewlap; TVD) and samples consisted of $20 \mathrm{~cm}$ of the central area minus the midrib as recommended by van Raij (2011).

Leaf samples collected as described were washed, stored in paper bags and dried in a hot house with forced air ventilation between $65-70^{\circ} \mathrm{C}$ until they reached a constant weight. The dried material was ground in a Wiley type mill with a $1 \mathrm{~mm}$ screen for determination of $\mathrm{K}$ in the plant tissue according to the method described by Bataglia et al. (1983).

Twelve months after sprouting, plants from the central lines in each parcel were collected and the aerial parts divided as leaves and stalks. After weighing the fresh material, $400 \mathrm{~g}$ of each part (leaves and stalks) were dried in a hot house $\left(65^{\circ} \mathrm{C}\right)$ and chemically analyzed for $\mathrm{K}$ as already stated. The $\mathrm{K}$ accumulation in the aerial plant part was calculated from the data. At harvest time, 10 stalks portion $^{-1}$ were collected for technological analysis by evaluation of sucrose levels (Pol\% cane), fiber, purity, concentration of soluble solids (Brix), theoretical sugar recovery (TSR), and reducing sugars determined according to the methods described by Consecana (2006).

Data were submitted to variance analysis followed by polynomial regression utilizing the software Agrostat (Barbosa and Maldonado Jr., 2011).

\section{Results and discussion}

Potassium dosages applied to the soil in ratoon cultures produced a linear increase in exchangeable $\mathrm{K}$ in the $0-20 \mathrm{~cm}$ deep layer in the first and second ratoon, 180 days after plant sprouting (Figure 1a) and also in the $20-40 \mathrm{~cm}$ layer in the second ratoon (Figure $1 \mathrm{~b}$ ).

Exchangeable $\mathrm{K}$ in soil of ratoon cultures fertilized with different $\mathrm{K}$ dosages, had maximal values, at the $0-20 \mathrm{~cm}$ depth, of 2.0 and $1.5 \mathrm{mmol} \mathrm{dm}{ }^{-3}$ in the first and second ratoon, respectively, 180 days after sprouting with a fertilizer dosage of $162 \mathrm{~kg} \mathrm{~K} \mathrm{ha}^{-1}$ (Figure 1a). Similar results were reported by Sampaio and Salcedo (1991), Mendonza et al. (2000), and Flores et al. (2012). The decreased level of soil $\mathrm{K}$ in the second ratoon probably occurred by extraction of the nutrient by successive crops (Rossetto et al., 2004). At the soil depth of $20-40 \mathrm{~cm}, 180$ days after sprouting, levels of $\mathrm{K}$ increased significantly only in the second ratoon (Figure $1 \mathrm{~b}$ ), but with lower results than the $0-20 \mathrm{~cm}$ depth. Similar 

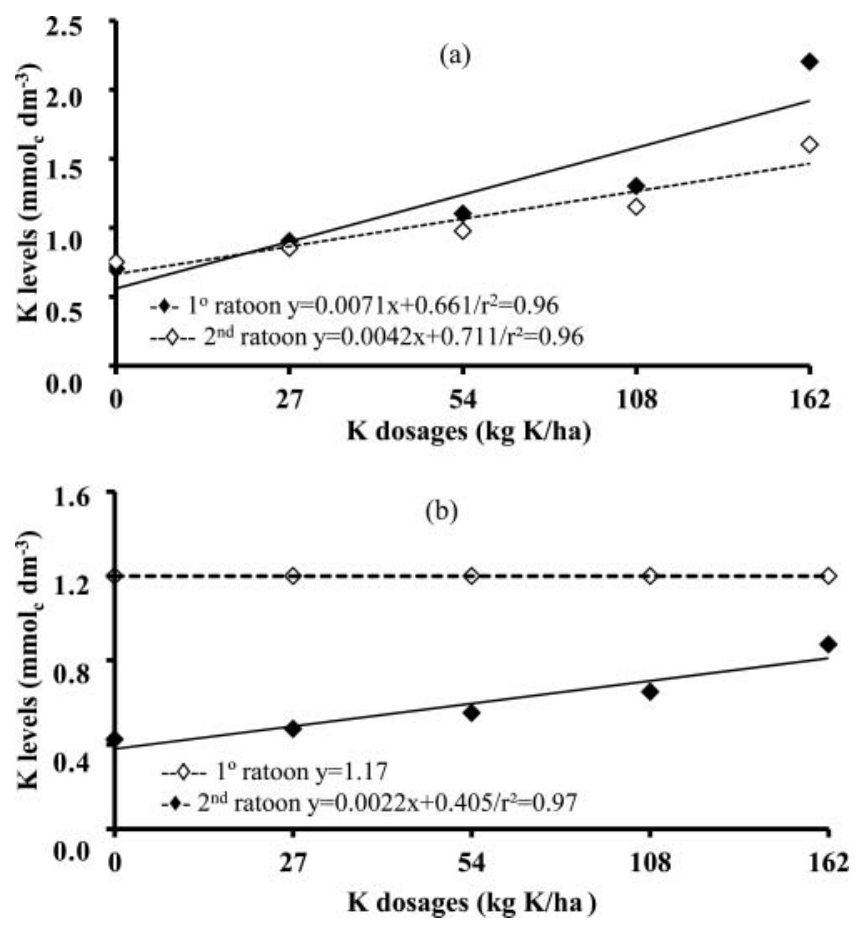

Figure 1. Effects of $\mathrm{K}$ dosages on the levels of exchangeable $\mathrm{K}$ determined in soil of ratoon cultures (first and second) in the city of Jardinopolis, SP, 180 days after plant sprouting, in samples taken at A) $0-20 \mathrm{~cm}$ and at B) $20-40 \mathrm{~cm}$ soil depth.

results were reported in the literature, confirming the decrease in $\mathrm{K}$ levels in increasing soil depths (Sampaio and Salcedo, 1991; Flores et al., 2012).

The diameter of cane sugar stalks showed a linear increase with a fertilizer dosage of $162 \mathrm{~kg} \mathrm{~K} \mathrm{ha}^{-1}$ only in the first ratoon $\left(y=0.011 x+18.692, r^{2}=0.47\right)$. The other growth variables as plant height and number of tillers were not influenced significantly in either the first or second ratoons by the application of the $\mathrm{K}$ fertilizer. It is to be noted that $\mathrm{K}$ fertilization does not seem to be important in the initial growth stages in cane sugar, an observation also made by Flores et al. (2012). The low incidence of rain in the months preceding growth evaluation should also be taking into account. The water availability was up to $70 \mathrm{~mm}$ during the first ratoon in the period of June to September 2009, whereas the hydric deficit was up to $64.84 \mathrm{~mm}$ during the second ratoon in the months of June to September 2010

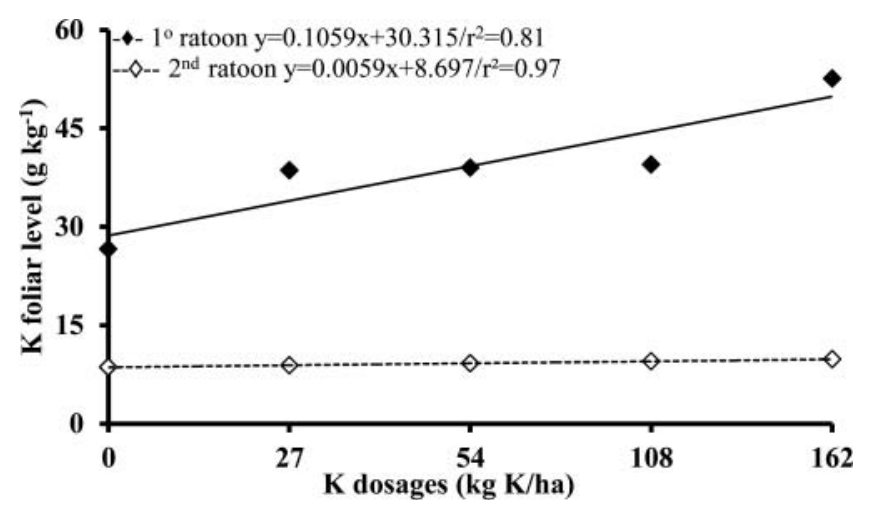

Figure 2. The effect of $\mathrm{K}$ soil fertilizer dosages on leaves +1 of cane sugar, 240 days after sprouting in the first and second ratoon cultures at the city of Jardinopolis. 
(Table 1). The movement of $\mathrm{K}$ in the soil is dependent on diffusion, which is affected by adequate water supply (Ramesh and Mahadevaswamy, 2000).

Application of $\mathrm{K}$ dosages in the soil produced linear increases in $\mathrm{K}$ levels in leaves +1 in the first and second ratoons, attaining maximal values of 51 and $9.8 \mathrm{~g} \mathrm{~kg}^{-1}$, respectively, when the fertilizer dosage was $162 \mathrm{~kg} \mathrm{~K} \mathrm{ha}^{-1}$ (Figure 2). Increased foliar levels of $\mathrm{K}$ in cane sugar ratoons as a function of $\mathrm{K}$ fertilization are reported widely in the literature (Rossetto et al., 2004).

Potassium fertilization linearly increased the nutrient accumulation in leaves (Figure 3a), stalks (Figure 3b), and aerial parts (Figure 3c) in sugar cane plants of the first ratoon culture, attaining maximal values of $184.8,96.4$, and $282.7 \mathrm{~kg} \mathrm{ha}^{-1}$, respectively. During the second ratoon, $\mathrm{K}$ fertilization
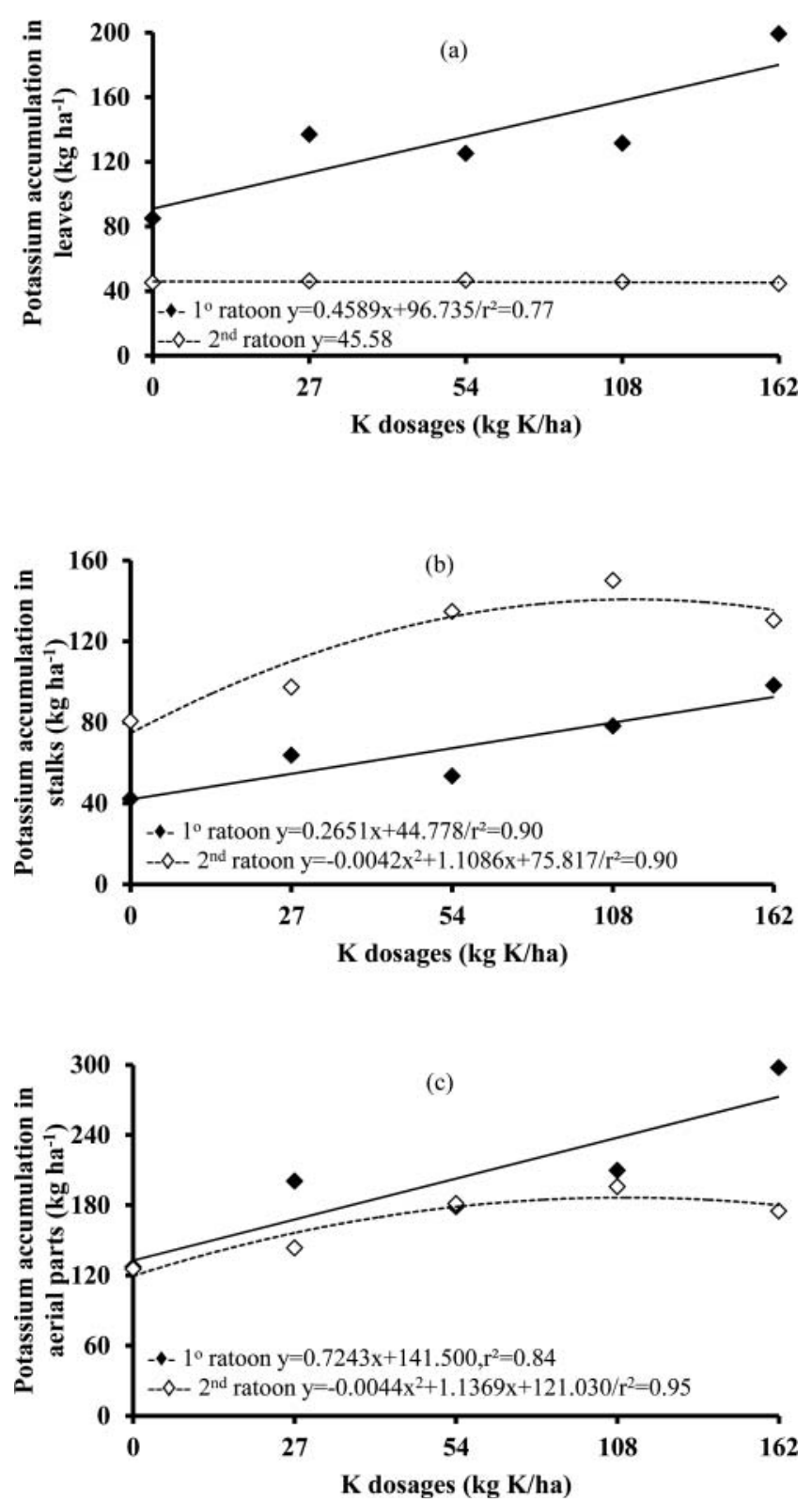

Figure 3 Effects of different potassium dosages applied to soil on the accumulation of nutrient in A) leaves, in B) stalk and C) aerial parts measured 360 days after sprouting in first and second sugar cane ratoons at the city of Jardinopolis. 
promoted increases with only in the nutrient accumulation in the stalks and aerial parts, and attained maximal values of 150 and $192 \mathrm{~kg} \mathrm{ha}^{-1}$ for fertilizer dosages of 110 and $107 \mathrm{~kg} \mathrm{~K} \mathrm{ha}^{-1}$, respectively.

The plant nutritional state as measured by leaf $\mathrm{K}$ showed a value of $51 \mathrm{~g} \mathrm{~kg}^{-1}$ in the first ratoon (Figure 2), higher than the concentrations considered adequate by van Raij (2011) and Wood and Meyer (1986) respectively, $10-16 \mathrm{~g} \mathrm{~kg}^{-1}$ and $>12 \mathrm{~g} \mathrm{~kg}^{-1}$. However, the different values quoted by the authors refer to cultures harvested after fire and also must be due to distinct edaphoclimatic conditions. The leaf $\mathrm{K}$ value in the second ratoon $\left(9.8 \mathrm{~g} \mathrm{~kg}^{-1}\right)$ is considered deficient and is probably due to reduced $\mathrm{K}$ absorption as shown by the low accumulation in leaves (Figure $3 \mathrm{a}$ ).

Potassium applied to the soil had a positive effect only in the stalk production in the first ratoon, showing a linear increase to a maximum of $120 \mathrm{t} \mathrm{ha}^{-1}$ at the dosage of $162 \mathrm{~kg} \mathrm{~K} \mathrm{ha}^{-1}$ (Figure 4). This result is probably due to the effect of $\mathrm{K}$ application already determined by the levels of nutrient in the soil (Figure 1), by the nutritional state of the plant (Figure 2), and by the growth of the first ratoon (diameter).

Similarly, Caione et al. (2011) and Ramesh and Mahadevaswamy (2000) observed that K application increased production in cane sugar ratoons due to the effect of the nutrient on plant growth.

Studies in the literature report distinct values of $\mathrm{K}$ dosages required for maximal production in cane sugar ratoons. High production of stalks was obtained when the dosage of $66 \mathrm{~kg} \mathrm{~K} \mathrm{ha}^{-1}$ was added to a Vertisoil in Mexico (Garcías et al., 2000); in Sudan, the best results in three soils (Dinder, Hagu and Nasr) were produced with $120 \mathrm{~kg} \mathrm{~K} \mathrm{ha}^{-1}$ (El-Tilib et al., 2004); in Brazil, the dosage of choice in a ratoon cultivated in a Red Yellow Argisoil was $184 \mathrm{~kg} \mathrm{~K} \mathrm{ha}^{-1}$ (Moura et al., 2005).

Water shortage during the experiments in this study could have been responsible for the lack of productivity in the second ratoon culture. It is suggested that production is dependent on the availability of water, an extremely important factor when the best yields in sugar cane are expected (Ribeiro et al., 1984). An appropriate supply of water in the initial phases and accelerated growth was shown to produce improvements in the agricultural and industrial yield of ratoon cane (Dantas Neto et al., 2006).

Potassium application to the soil produced quadratically adjusted increases only in some quality parameters restricted to the first ratoon, as in Brix $\left(y=0.000003 x^{2}-0.0039 x+17.395 ; r^{2}=0.75\right)$ and in Theoretically Recoverable Sugar (TRS) $\left(y=0.0007 x^{2}-0.1352 x+128.84 ; r^{2}=0.99\right)$. It is to be noted that the $\mathrm{K}$ effect on plant quality was relatively low with poor agronomical importance. Similar results on the effects of $\mathrm{K}$ fertilization on the quality of juice from ratoon cane were verified by other authors (Garcías et al., 2000; Feltrin et al., 2010; Caione et al., 2011).

Potassium fertilization in the first cane sugar ratoon increased stalk diameters and production, improved the nutritional state of the plants and increased $\mathrm{K}$ accumulation in aerial parts. Water deficiency conditions were present in the second ratoon culture and $\mathrm{K}$ application did not influence plant growth, nutritional status, or production. Potassium application to soil in sugar cane ratoon cultures was not important for the improvement of the technological quality of stalks.

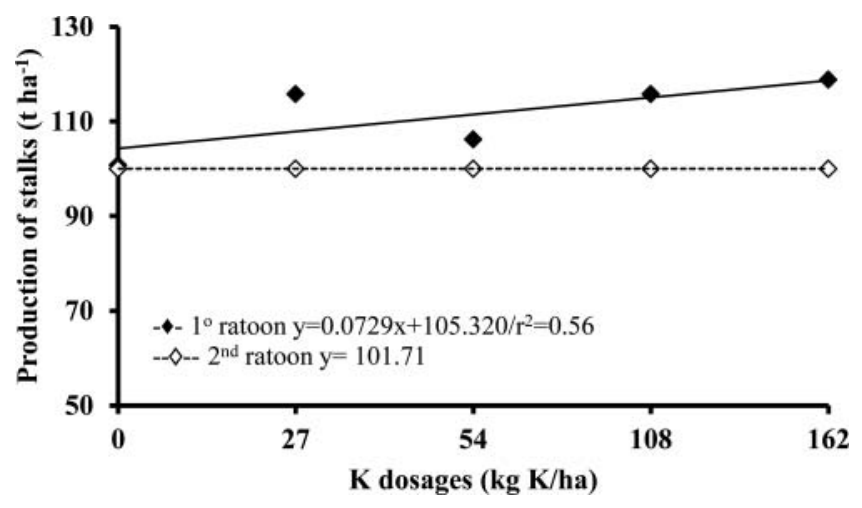

Figure 4. Effect of different $\mathrm{K}$ dosages applied to the soil on the production of stalks, 360 days after sprouting in the first and second ratoon cultures of cane sugar at the city of Jardinopolis. 


\section{References}

Ageitec. "Embrapa Agency for Technological Information (Agência Embrapa de Informação Tecnológica).” Available at: https://www.agencia.cnptia.embrapa.br/gestor/cana-de-acucar/arvore/CONTAG01_92_22122006154841. html (accessed 19 January 2013).

Barbosa, J. C., and W. Maldonado Júnior. 2011. AgroEstat: Sistema para análise estatística de ensaios agronômicos). [AgroEstat: a system for statistical analysis of agronomic assays], Version 1.0. Jaboticabal, Brazil: FCAV/Unesp.

Bataglia, O. C., A. M. C. Furlani, J. P. F. Teixeira, P. R. Furlani, and J. R. Gallo. 1983. Métodos de Análise Química de Plantas [Methods for chemical analysis of plants]. Campinas, Brazil: Agronomic Institute of Campinas.

Benedini, M. S., and C. P. Penatti. 2008. Recomendação de adubação da cana-de-açúcar pela estimativa de produtividade [Recommended fertilization of sugarcane cultures based on estimates of productivity]. Revista Coplana 5: 20-21.

Caione, G., A. F. Silva, L. L. Reis, F. C. Dalchiavon, M. T. R. Teixeira, and P. A. Santos. 2011. Doses de potássio em cobertura na primeira soca da cultura da cana-de-açúcar cultivada no norte Matogrossense [Potassium doses in top-dressing of a first sugarcane ratoon culture in the north of the State of Mato Grosso]. Bioscience Journal 27: 572-580.

Cantarella, H. 1998. Aplicação de nitrogênio em sistema de cana-crua [Nitrogen application in the crude-cane system].) STAB - Sugar, Alcohol and By-Products 16: 21-22.

Ciiagro. 2003. Centro integrado de informações agrometeorológicas [Integrated cente of agro-meteorological information]. Available at: http://www.ciiagro.sp.gov.br/ciiagroonline/menuresenha.htm (accessed 1 January 2012).

Conab. 2012. Acompanhamento da safra brasileira de cana-de-açúcar [Survey of brazilian sugarcane]. Available at: http:// www.conab.gov.br/OlalaCMS/uploads/arquivos/12_08_09_15_07_05_boletim_cana_portugues_-_agosto_2012_2o_ lev.pdf.

Consecana. 2006. Instruction manual (Manual de instruções), eds. Consecana. Available at: http://www.orplana.com.br/ manual_2006.pdf (accessed 16 February 2012).

Dantas Neto, J., J. L. C. Figueiredo, C. H. A. Farias, H. M. Azevedo, and C. A. V. Azevedo. 2006. Resposta da cana-deaçúcar, primeira soca, a níveis de irrigação e adubação de cobertura [Response of sugarcane first ratoon to irrigation levels and top-dressing fertilization]. Revista Brasileira de Engenharia Agrícola e Ambiental 10: 283-288.

El-Tilib, M. A., M. H. Elnasikh, and E. A. Elamin. 2004. Phosphorus and potassium fertilization effects on growth attributes and yield of two sugarcane varieties grown on three soil series. Journal of Plant Nutrition 27: 663-699.

Embrapa. 2006. Sistema Brasileiro de Classificação de Solos [Brazilian system of soil classification]. Rio de Janeiro, Brazil: Centro Nacional de Pesquisa de Solos.

Feltrin, M. S., M. G. D. P. Lavanholi, H. S. Silva, and R. M. Prado. 2010. Adubação potássica na produtividade da soqueira de cana-de-açúcar colhida sem queima [Effect of $\mathrm{K}$ fertilization in the productivity of sugarcane ratoon cultures harvested without burning]. Nucleus 7: 307-314.

Flores, R. A., R. M. Prado, L. S. Politi, and T. B. F. Almeida. 2012. Potassium in the early development stage of unburned sugarcane ratoon cultures (Potássio no desenvolvimento inicial da soqueira de cana crua). Pesquisa Agropecuária Tropical 42: 106-111.

Garcías, S. S., R. N. Escorba, J. J. P. Cabriales, J. D. E. Barra, D. J. P. López, and M. R. S. Hernández. 2000. Respuesta de la soca caña de azucar a la fertilización NPK [Response of sugarcane ratoon cultures to NPK]. Agrociência 34: 689-698.

Mendonza, H. N. S., E. Lima, L. H. C. Anjos, L. A. Silva, M. B. Ceddia, and M. V. M. Antunes. 2000. Propriedades químicas e biológicas de solo de tabuleiro cultivado com cana-de-açúcar com e sem queima da palhada [Chemical and biological properties of tableland soil cultivated with sugar cane with and without straw burning]. Revista Brasileira de Ciência do Solo 24: 201-207.

Moura, M. V. P. S., C. H. A. Farias, C. A. V. Azevedo, J. D. Neto, H. M. Azevedo, and R. V. Pordeus. 2005. Doses de adubação nitrogenada e potássica em cobertura na cultura da cana-de-açúcar, primeira soca, com e sem irrigação [Levels of $\mathrm{N}$ and $\mathrm{K}$ in top-dressing fertilization of the sugarcane first ratoon cultures with and without irrigation]. Ciência Agrotecnologia 29: 753-760.

Oliveira, E. C. A. 2008. MSc. dissertation, Universidade Federal Rural de Pernambuco, Recife, Brazil. Available at: http:// 200.17.137.108/tde_busca/arquivo.php?codArquivo=226 (accessed 28 February 2013).

Oliveira, M. W., P. C. O. Trivelin, G. J. C. Gava, and C. P. Penatti. 1999. Degradação da palhada de cana-de-açúcar [Sugarcane straw degradation]. Scientia Agrícola 56: 803-809.

Ramesh, P., and M. Mahadevaswamy. 2000. Effect of formative phase drought on different classes of shoots, shoot, mortality, cane attributes, yield and quality of four sugarcane cultivars. Journal Agronomy \& Crop Science 185: 249-258.

Reis Junior, R. A. 2001. Probabilidade de resposta da cana-de-açúcar à adubação potássica em razão da relação $\mathrm{K}^{+}$ $\left(\mathrm{Ca}^{2++} \mathrm{Mg}^{2+}\right)^{-0,5}$ do solo [Probability of sugarcane response to potassium fertilization as a function of soil $\mathrm{K}^{+}$ $\left(\mathrm{Ca}^{2++} \mathrm{Mg}^{2+}\right)^{-0,5}$ ratio]. Pesquisa Agropecuária Brasileira 36: 1175-1183.

Ribeiro, M. R., E. H. Halstead, and E. Jong. 1984. Rendimento da cana-de-açúcar e características das terras da microrregião da Mata Norte de Pernambuco [Yields of sugarcane and soil characteristics in the microregion of mata norte in the state of Pernambuco]. Revista Brasileira de Ciência do Solo 8: 209-213.

Rossetto, R., A. Spironello, H. Cantarella, and J. A. Quaggio. 2004. Calagem para a cana-de-açúcar e sua interação com a adubação potássica [Sugarcane response to liming and potassium fertilization]. Bragantia 63: 105-119. 
Sampaio, E. V. S. B., and I. H. Salcedo. 1991. Dinâmica de nutrientes em cana-de-açúcar. V. Balanço de K em quatro ciclos de cultivo [Nutrient dynamics in sugarcane.V. Potassium balance in four cycles of culture]. Pesquisa Agropecuária Brasileira 26: 1323-1335.

Schultz, N., E. Lima, M. G. Pereira, and E. Zonta. 2010. Efeito residual da adubação na cana-planta e da adubação nitrogenada e potássica na cana-soca colhidas com e sem a queima da palhada [Residual effects of nitrogen, potassium and vinasse, fertilization on cane plant and ratoon harvested with and without straw burning]. Revista Brasileira de Ciência do Solo 34: 811-820.

Spironello, A., B. V. Raij, C. P. Penatti, H. Cantarella, J. L. Morelli, J. Orlando Filho, M. G. A. Landell, and R. Rosseto. 1997. Cana-de-açúcar [Sugar cane]. In: Recomendações de Adubação e Calagem para o Estado de São Paulo [Recommendations in fertilization and liming in the State of São Paulo (], eds. B. V. Raij, H. Cantarella, J. A. Quaggio, and A. M. C. Furlani, pp. 237-239. Campinas, Brazil: IAC.

van Raij, B. 2011. Avaliação do estado nutricional das plantas [Evaluation of plant nutritional status]. In: Fertilidade do Solo e Manejo de Nutrients [Soil Fertility and Management of Nutrients], eds B. van Raij, pp. 157-171. Piracicaba, Brazil: International Plant Nutrition Institute.

van Raij, B., J. C. Andrade, H. Cantarella, and J. A. Quaggio. 2001. Análise Química para Avaliação da Fertilidade de Solos Tropicais [Evaluation of fertility in tropical soils by chemical analysis]. (Campinas, Brazil: Agronomic Institute of Campinas.

Weber, H., E. Daros, J. L. C. Zambon, O. T. Ido, and J. D. Barela. 2002. Recuperação da produtividade de soqueiras de cana-de-açúcar com adubação NPK [Raton sugar cane productivity recovery with NPK fertilization]. Scientia Agraria 2: $73-77$.

Wood, R. A., and J. H. Meyer. 1986. Factors affecting potassium nutrition of sugarcane in South Africa. Proceedings of The South African Sugar Technologists' Association 5: 198-204. 